\title{
Talent Management in Innovative Enterprises
}

\author{
Sylwia Wiśniewska \\ Cracow University of Economics \\ E-mail: sylwia.wisniewska@uek.krakow.pl \\ Kamil Wiśniewski \\ The Jan Kochanowski University \\ E-mail: kamil.wisniewski@ujk.edu.pl
}

Doi:10.5901/ajis.2013.v2n3p329

\section{Abstract}

The article aims to show aspects from the scope of talent management, which should be introduced in an innovative enterprise. On the basis of analysis of literature and observations made during research visits in innovative enterprises, the authors determined collection of elements belonging to the talent management area, which should be considered as part of human resource management in an innovative company. This elements do not exhaust the possibility to extend human resource management in innovative enterprises by elements included in talent management. They are only examples of possible adjustment of human resource management to demands of talents, which should lead to increase of effectiveness of their work in an innovative enterprise.

Keywords: talent; talent management; human resource management; knowledge; innovation; innovativeness; innovative enterprise

\section{Introduction}

Dynamic changes on the markets, which are the result of the increasing competition and fast technical progress, encourage companies to actively seek and create knowledge, and to use it in order to increase their innovative character. The knowledge contained in a company and its workers, as well as innovations which are the result of using and developing that knowledge, are presently becoming the source of long-term competitive advantage on the markets and the indicator of economic success in the conditions of globalisation and the knowledge-based economy (Dolińska, 2010a).

Entrepreneurs, which are aware of significance of knowledge, look for employees in their environment, who are particularly talented, have exceptional skills, very high development and are committed to their work. Often the employees also have outstanding achievements and are referred to as talent (Mikuła, 2007). Innovation leaders are a specific group of talent and play a key role in innovation processes.

The need to employ and manage talented employees appropriately is especially significant in case of innovative enterprises, which are oriented on permanent creating of innovation on the basis of their employees' knowledge. The problem identified by the authors and relating to talent employed in innovative enterprises is frequent lack of comprehensive management of talents in such types of enterprises. Unfortunately, human resource management (HRM) usually does not consider specific needs of talented employees. Therefore, the article aims to show aspects from the scope of talent management (TM), which should be introduced in an innovative enterprise.

\section{Literature Review}

This section looks at the various definitions of innovative enterprises and talent management.

\subsection{Definitions of innovative enterprises}

In literature one may find numerous definitions of innovations, innovativeness, innovation processes and knowledge, which refer to the term "innovative enterprises". The "Oslo Manual" (2005) is the commonly accepted international 
methodological standard, presently applied in all countries conducting statistical research on innovation. It was prepared by a group of OECD experts. In accordance with the methodology of "Oslo Manual" (2005), innovations include the implementation of the new and greatly upgraded product (product innovation), process (process innovation), new marketing activity (marketing innovation) or a new organizational method (organizational innovation). Therefore, innovativeness is the ability to generate and implement different types of innovations, notably: product, process, organizational and marketing innovations.

In our times, innovations are integral elements of changes occurring in economy, and they include both technical, as well as economic and social undertakings. That is because innovations are ideas transformed into concrete products or services satisfying specific needs, with the simultaneous generation of profit, multiplication of the value of invested capital and the creation of competitive advantage of a company, region, country (Duraj, Papiernik-Wojdera, 2010).

Innovations are created in companies in the framework of carrying out innovation processes. Such a process can be described as "a sequence of repetitive in time activities from the moment of the creation of an idea of a new solution, through developing, implementing, promoting and selling the innovation on the market, as well as its diffusion and its further development in time" (Dolińska, 2010b, p. 149). Moreover, the innovation process is the process oriented at developing new, or changed to a great extent, goods, services, processes and solutions in the scope of marketing, as well as organizational methods. This process comprises the following phases:

1. acquiring or generating ideas,

2. developing a new solution,

3. testing the solution,

4. implementation of innovations,

5. marketing,

6. sale,

7. innovation diffusion (see: Dolińska, 2006; Knox, 2002).

Innovations are the products of knowledge and the results of innovation processes in which knowledge is obtained, flows, is used and developed (Brdulak, 2003). Therefore, knowledge plays a crucial part in each phase of the innovation process (Barczak, 2006). Noticing the significance of knowledge in economy, Drucker (1999) defined it as the effective use of information. Whereas Davenport and Prusak (2000) state that knowledge is a smooth connection of acquired experience, values, context information and expert approach which constitute the framework for the assessment and inclusion of new experiences and information. It comes from the minds of the experts and is used in them. In organizations, it can often be found in documents or repositories, but also in organizational procedures, processes, practices or standards. In turn, Nonaka and Takeuchi $(2000$, p. 80), in the theory of organizational creation of knowledge, accept the traditional definition of knowledge as "confirmed belief". The authors of the paper concur with the view of Mikuła (2011) who indicates that at present the definitions are quoted which present knowledge as: providing information and understanding it and confirmed conviction.

Summing up the question of defining the notion of innovative companies, for the purposes of this study, it was assumed that an innovative enterprise, as understood by the methodology of the "Oslo Manual" (2005), is such a enterprise which in the examined period of time launched at least one (product, process, marketing or organizational) innovation.

The fundamental features of an innovative company include:

- the capability to generate innovations permanently,

- the ability to take advantage of the innovative potential of a company to achieve and maintain a high competitive position,

- the capability to think long-term,

- permanent contact with customers in order to learn about their current and future expectations effectively,

- having a team of innovators which would guarantee a high level of the innovative character of a company,

- flexibility of activities in adjusting to the changing environment (Sosnowska, 2000),

- a large number of new products and technologies developed in a given period,

- a considerable share of new products and technologies in the annual sales volume,

- a considerable number and value of the obtained patents,

- a high degree of modernity and ecological character of the used technologies,

- informatization (Barczak, Bartusik, Kozina, 2009),

- conducting research and development activities and allotting considerable sums of financial resources to them, 
- focusing on key competences and investing in them (Bielski, 2007),

- treating knowledge management as the key factor to success,

- organizational learning (Brzeziński, 2000).

\subsection{Definitions of talent management}

In literature one may find numerous definitions of talent. Moreover, there is no consensus on the meaning of talent. Generally indicates talent in the following areas:

- innovation,

- personal contacts,

- leadership,

- production of goods or provide services,

- information processing (Kopeć, 2012).

Gagne (2000) talent defined as the superior mastery of systematically developed abilities and knowledge in at least one field of human endeavour. Listwan (2005) talent understood as people with outstanding potential. In accordance with Renzulli's practical model of outstanding talent, talent is combined of:

- superior skills - which include general skills (high intellectual potential) and specific skills (for specific areas),

- creativeness - originality, novelty, fluency and flexibility of thinking, solving new and unconventional problems, openness to ambiguity and uncertainty, risk taking and rich emotional sensitivity,

- commitment to work - self-discipline, perseverance in achieving the aim, hard work, the fascination of work, willingness to sacrifice, aware of their own capabilities (Sękowski, 2004).

Innovation leaders are a specific group of talents and play a key role in innovation processes. Deschamps (2011), innovation leaders defines as executive managers who promote innovation as an element of strategy of their companies. Regardless of the function performed by them or the position in the organizational structure in a company, they are to guarantee that innovation processes are carried out properly in their companies, and build such organizational culture that is favourable to innovation. Innovation in comparison with the more traditional business leaders, innovation leaders possess a set of distinguishing attributes:

- combination of creativity and discipline,

- accepting uncertainty, risk and failures combined with the ability to make teams aware of how to learn from them what will allow to limit those factors in the future,

- high degree of personal commitment in the mission of increasing innovation of a company and motivating subordinates to be active in this scope,

- readiness to seek technologies and ideas outside the company,

- inclination to experiment,

- ability to assess the carried out innovative projects,

- $\quad$ talent for creating human teams and managing them, and to recruiting innovators and making them stay.

Lewis and Heckman (2006) defined three types of conceptualisations of TM:

1. a collection of typical human resource management practices,

2. talent flows of employees into jobs in an enterprise,

3. a generic perspective on talent that focuses on high-performing and high-potential employees and talent in general.

Similarly, according to Listwan (2005, p. 21) talent management is a "collection of activities related to exceptionally talented persons and undertaken with the aim to ensure their development and efficiency and attainment of targets on an organisation".

Stone (2009) human resource management describes it as the productive use of human resources in achieving the organization's strategic business objectives (Fong, Ooi, Tan, Lee, Chong, 2011). A broader definition of HRM is presented by Pawlak (2011). In his opinion, human resource management is a current approach to the implementation of the personnel function of an organization. It consists in proper formulation and use of human resources to achieve company objectives, taking into account the interests of both employers and employees. HRM is based on the former scientific achievements concerning organizations and management, also bearing in mind the state of economic development, especially the increase of competition on the market, as well as the globalization of economic, social and political relations.

The level of innovation of each organization is determined by the effectiveness of talent and innovation leaders, 
who are a specific group of talent of these organizations. They should in fact create innovative knowledge reflected in new products, processes, and new marketing and organizational solutions. In turn, human resource management practices play the key role in talent management in an innovative enterprise and have a major impact on the effectiveness of innovative companies. Therefore, in this work, the notion of talent management means a collection of human resource management practices that are constructed to attract and develop talent, who are valid in achieve aims of innovative enterprises.

\section{Findings and Discussion}

In the authors' opinion, innovativeness is the key attribute of talent and it should be supported by HRM activities. The problem identified by the authors and relating to talent employed in innovative enterprises is frequent lack of comprehensive talent management in such types of enterprises. Therefore, human resources management usually does not consider specific needs of talented employees.

Moreover, as Mikuła (2007) emphasizes, a significant problem is that employees referred to as talent:

- do not want to be bound to an employed by a long-term employment agreement;

- are not easily persuaded to undertake work in a given enterprise tempted only by an incentive such as attractive remuneration, as they also expect an opportunity to create something exceptional and use their knowledge and acquire new knowledge as well as fulfil themselves;

- want considerable autonomy and do not agree to limitation of their independence by discipline of work as regards the fixed time of work and detailed targets imposed by principals;

- require respect and often good conditions of teamwork.

An attempt to solve the problems is so-called talent management. Therefore, this article aims to show aspects from the scope of TM, which should be introduced in an innovative enterprise. On the basis of analysis of literature and observations made during research visits in innovative enterprises, the author determined the following collection of elements belonging to the talent management area, which should be considered as part of human resources management in an innovative company:

- constant search for talented employees, including, among the company's staff;

- propagation among the staff a conviction that talented employees are a key source of innovation and, therefore, the most important resource of an enterprise, which enables it to generate profits and attain competitive advantage;

- acceptance of high risk of failure of innovative activities conducted by talented employees and admission of mistakes during realisation of innovative projects;

- giving a talented employee the opportunity to work in several places, e.g. at a university, a research and development institution (it is often assumed that preventing a talented employee from doing additional work will make him/her work more effectively, which, considering the constant need to deepen knowledge, may lead to decrease of the effectiveness);

- enabling talented persons to exchange and deepen their knowledge during training, scientific conferences, specific fairs, quality circles and practice communities;

- consideration of great influence of the atmosphere and conditions of work on the comfort of creative thinking (listening to relaxation music at work, longer breaks and even such unconventional solutions as the possibility to nap at work);

- high autonomy as regards methods of work;

- an incentive system considering incentives other than remuneration and clearly defined possibilities of promotion;

- $\quad$ enabling talented employees to face even newer challenges, which is to prevent a burnout syndrome;

- encouraging talented employees to use methods of creative thinking and problem solving;

- use of teamwork to a wide extent, including, interdisciplinary teams, which favour creation of unconventional solutions and exchange of knowledge;

- flexible time of work;

- access to the most recent technical and telecommunications and IT infrastructure;

- clearly defined rules of evaluation of works of talented employees;

- enabling talented employees to do a considerable part of their work at home or in other places outside the company, where they do their work best; 
- enabling talented employees to personalise their place and organisation of work to a considerable extent;

- innovative organisational culture;

- coaching and mentoring by talented employees.

\section{Concluding Remarks}

The need to employ and manage talented employees appropriately is especially significant in case of innovative enterprises, which are oriented on permanent creating of innovation on the basis of their employees' knowledge. The level of innovation of each organization is determined by the effectiveness of talent and innovation leaders, who are a specific group of talent of these organizations. They should in fact create innovative knowledge reflected in new products, processes, and new marketing and organizational solutions. Effective talent management is a challenge for innovative enterprises. Indeed, they must adapt human resource management practices to the requirements of talent management. Therefore, the problem which can be observed in many innovative companies is the inability to manage talent who are not treated as a specific group of workers, while managing talent requires a special approach from the human resource management practices.

Furthermore, it is particularly important to get to know the attributes of talent (the specific group of workers), which should help in the more efficient managing of talent and their knowledge, and this in turn should translate into the increase of innovativeness of a company. In addition, it is the priority to connect the human resource management strategy with the talent management strategy, and the skilful creating and implementing the right organizational culture supporting talent management. In authors' opinion, the discussed human resources management practices can significantly support talent who are innovators in their work. The above-mentioned elements do not exhaust the possibility to extend HRM in innovative enterprises by elements included in talent management. They are only examples of possible adjustment of human resources management to demands of talents, which should lead to increase of effectiveness of their work in an innovative enterprise.

\section{References}

Barczak, B., Bartusik, K. and Kozina A. (2009). Modele strukturalne organizacji uczącej się. In: Doskonalenie struktur organizacyjnych przedsiębiorstw w gospodarce opartej na wiedzy. ed. Stabryła, A. Warszawa: Wydawnictwo C.H. Beck.

Barczak, B. (2006). Zarządzanie wiedza jako czynnik zwiększania potencjału innowacyjnego firmy. In: Zeszyty Naukowe Akademii Ekonomicznej w Krakowie. No. 700. ed. Stabryła, A. Kraków: Wydawnictwo Akademii Ekonomicznej w Krakowie.

Bielski, I. (2007). Zarządzanie wiedzą w przedsiębiorstwie innowacyjnym. Nowe koncepcje zarządzania jako odpowiedź na zmiany w środowisku biznesu. In: Studia i Materiały Polskiego Stowarzyszenia Zarządzania Wiedzą. No. 8. ed. Bojar, W. Bydgoszcz: Polskie Stowarzyszenie Zarządzania Wiedza.

Brdulak, J. (2003). Zarządzanie wiedza a innowacyjność. In: Błaszczuk, A., Brdulak, J.J., Guzik, M. and Pawluczuk, A. Zarządzanie wiedzą w polskich przedsiębiorstwach. Warszawa: Wydawnictwo Szkoły Głównej Handlowej w Warszawie.

Brzeziński, M. (2000). Proces uczenia się zmian. Przegląd Organizacji. No. 3.

Davenport, T.H. and Prusak L. (2000). Working Knowledge. How Organizations Manage What They Know. Boston, Massachusetts: Harvard Business School Press.

Deschamps, J.P. (2011). Liderzy innowacyjności. Jak rozwijać i utrzymywać innowacyjność w firmie. Warszawa: Oficyna a Wolters Kluwer business.

Dolińska, M. (2010a). Innowacje w gospodarce opartej na wiedzy. Warszawa: PWE.

Dolińska, M. (2010b). Uwarunkowania organizacyjne i rynkowe rozwoju innowacyjnego przedsiębiorstw w województwie lubelskim. In: Polityka ekonomiczna. Prace naukowe Uniwersytetu Ekonomicznego we Wrocławiu. No. 111, ed. Sokołowski, J., Sosnowski, M. and Żabiński, A. Wrocław: Uniwersytet Ekonomiczny we Wrocławiu.

Dolińska, M. (2006). Wpływ kapitału intelektualnego organizacji na rozwój innowacji, E-mentor. №. 2.

Drucker, P. (1999). Społeczeństwo pokapitalistyczne, Warszawa: PWN.

Duraj, J. and Papiernik-Wojdera, M. (2010). Przedsiębiorczość i innowacyjność. Warszawa: Difin.

Gagne, F. (2000). Understanding the complete choreography of talent development through DMGT-based analysis. In: International Handbook of Giftedness and Talent, eds. Heller, K.A., Monks, F.J., Subotnik, R.F. and Sternberg, R.J. Oxford: Elsevier Science.

Knox, S.J. (2002). The boardroom agenda: developing the innovative organization. Corporate Governance. No. 1.

Kopeć, J. (2012). Zarządzanie talentami w przedsiębiorstwie. Kraków: Wydawnictwo Uniwersytetu Ekonomicznego w Krakowie.

Lewis, R.E. and Heckman, R.J. (2006). Talent management: a critical review, Human Resource Management Review. Vol. 16. No. 2.

Listwan, T. (2005). Zarządzanie talentami - wyzwanie współczesnych organizacji. In: Zarządzanie talentami. ed. Borkowska, S. Warszawa: Instytut Pracy i Spraw Socjalnych.

Mikuła, B. (2011). Istota zarządzania wiedzą w organizacji. In: Komunikacja w procesach zarządzania wiedzą. ed. Potocki, A. Kraków: Fundacja Uniwersytetu Ekonomicznego w Krakowie. 
Mikuła, B. (2007). Zarządzanie talentami, In: Podstawy zarządzania przedsiębiorstwami w gospodarce opartej na wiedzy. ed. Mikuła, B., Pietruszka-Ortyl, A., Potocki, A. Warszawa: Difin.

Nonaka, I. and Takeuchi, H. (2000). Kreowanie wiedzy w organizacji. Jak spółki japońskie dynamizują procesy innowacyjne. Warszawa: Poltext.

Oslo Manual. Guidelines for Collecting and Interpreting Innovation Data (2005). Third Edition. Paris: OECD, Eurostat.

Pawlak, Z. (2011). Zarządzanie zasobami ludzkimi w przedsiębiorstwie. Warszawa: Poltext.

Sękowski, A.E. (2004). Psychologiczne uwarunkowania wybitnych zdolności. In: Psychologia zdolności. Współczesne kierunki badań. ed. Sękowski, A.E. Warszawa: PWN.

Sosnowska, A. (2000). Systemy zarządzania firmą innowacyjną. In: Zarządzanie firmą innowacyjną. ed. Sosnowska, A., Łobejko, S., Kłopotek, A. Warszawa: Difin.

Stone, R.J. (2009), Managing Human Resources: An Asian Perspective, Milton: John Wiley \& Sons, cited by: Fong, Ch.Y., Ooi, K.B., Tan, B.I., Lee, V.H., Chong, A.Y.L. (2011), HRM practices and knowledge sharing: an empirical study, International Journal of Manpower. No. 5/6. 